\title{
Apparent and standardized ileal nutrient digestibility of broiler diets containing varying levels of raw full-fat soybean and microbial protease
}

\author{
Mammo M. Erdaw ${ }^{1,3^{*}}$, Rider A. Perez-Maldonado ${ }^{2}$ and Paul A. lji ${ }^{1^{*}}$
}

\begin{abstract}
Background: Although soybean meal (SBM) is excellent source of protein in diets for poultry, it is sometimes inaccessible, costly and fluctuates in supply. The SBM can partially be replaced by full-fat SBM, but the meals prepared from raw full-fat soybean contain antinutritional factors. To avoid the risk of antinutritional factors, heat treatment is always advisable, but either excessive or under heating the soybean could negatively affect the quality. However, the potential for further improvement of SBM by supplementing with microbial enzymes has been suggested by many researchers. The objective of this study was to evaluate the performance and ileal nutrient digestibility of birds fed on diets containing raw soybeans and supplemented with microbial protease.
\end{abstract}

Methods: A $3 \times 2$ factorial, involving 3 levels of raw full-fat soybean (RFFS; 0,45 or $75 \mathrm{~g} / \mathrm{kg}$ of diet) and 2 levels of protease (0 or 15,000 PROT/kg) was used. The birds were raised in a climate-controlled room. A nitrogen-free diet was also offered to a reference group from day 19 to 24 to determine protein and amino acid flow at the terminal ileum and calculate the standardized ileal digestibility of nutrients. On days 10, 24 and 35, body weight and feed leftover were recorded to calculate the body weight gain (BWG), feed intake (FI) and feed conversion ratio (FCR). On day 24, samples of ileal digesta were collected at least from two birds per replicate.

Results: When RFFS was increased from 0 to $75 \mathrm{~g} / \mathrm{kg}$ of diet, the content of trypsin inhibitors was increased from 1747 to 10,193 trypsin inhibitors unit (TIU)/g of diets, and feed consumption of birds was also reduced $(P<0.05)$. Increasing RFFS level reduced the BWG from hatch 0 to $10 \mathrm{~d}(P<0.01)$ and hatch to $24 \mathrm{~d}(P<0.05)$. The BWG of birds from hatch to 35 was not significantly $(P=0.07)$ affected.

Feed intake was also reduced $(P<0.05)$ during 0 to $35 \mathrm{~d}$. However, protease supplementation improved $(P<0.05)$ the BWG and FCR during 0 to $24 \mathrm{~d}$. Rising levels of RFFS increased the weight of pancreas $(P<0.001)$ and small intestine $(P<0.001)$ at day 24 . Except for methionine, apparent and the corresponding standardized ileal digestibility of $C P$ and AA were reduced $(P<0.01)$ by increasing levels of RFFS in diets.

Conclusion: This study showed that some commercial SBM could be replaced by RFFS in broiler diets, without markedly compromising productivity. The AID and SID of CP and lysine were slightly improved by dietary supplementation of microbial protease.

Keywords: Amino acids, Antinutritional factors, Broilers, lleal digestibility, Microbial protease, Trypsin inhibitors

\footnotetext{
* Correspondence: leulmammo@yahoo.com; piji@une.edu.au

${ }^{1}$ School of Environmental and Rural Sciences, University of New England,

Armidale, NSW 2351, Australia

Full list of author information is available at the end of the article
} 


\section{Background}

It is well established that commercial soybean meal (SBM) is an excellent source of protein in diets for poultry [1]. However, in addition to the fluctuation in supply and seasonal scarcity in some parts of the world, the price of SBM has been increasing over the years [1, 2]. Poultry producers therefore continuously seek alternative ingredients, including full-fat SBM to replace some or all the commercial SBM in diets for broilers [3]. Full-fat soybean meal is typically made from heat-treated seeds; and it is less common to feed soybean as raw. Such processing plants are lacking in some areas of the world where soybeans are locally produced and poultry producers could save some costs if the raw soybean could be fed. However, raw soybean seeds contain considerable amounts of ANF, particularly trypsin inhibitors (TI), which depress growth in non-ruminant animals [4-7]. The presence of dietary TI in legumes, such as soybeans causes a substantial reduction in the digestibility (up to $50 \%$ ) of proteins and AA and protein quality (up to 100\%) in non-ruminant animals [8]. Nitrogen $(\mathrm{N})$ retention can also be negatively affected by TI causing an increased endogenous $\mathrm{N}$ loss [9, 10]. Although Barth et al. [11] reported that inclusion of RFFS in diets caused loss of endogenous protein, Clarke and Wiseman [12] reported that AA digestibility did not correlate with levels of RFFS supplementation/concentration of TI.

Although heating is considered to be the most effective method to eliminate or reduce ANF, some of the ANF in soybeans, such as the Bowman-Birk inhibitors, phytates and oligosaccharides are not heat-labile. These ANF remain a problem in feeds prepared from raw soybean grains and poorly processed commercial meals. Clemente et al. [13] also reported that Bowman-Birk inhibitors exhibit resistance to heat treatment, so that supplementation of such corn-soybean meal diets with microbial enzymes including protease and phytase is necessary $[10,14]$.

The potential for further improvement in the nutritional value of soybeans using exogenous enzymes has therefore been suggested by many researchers $[5,12,15,16]$. The negative effects of microbial protease supplementation of poultry diets have been widely documented [17-19]. However, the role of such enzymes on RFFS has not been adequately investigated. In recent in vitro and in vivo studies, we reported the positive response of protein and phytate in RFFS to microbial protease and phytase and gross response of poultry on such test diets [20-23]. The objective of the current study was to assess how these enzymes, particularly protease, affect CP and AA digestibility.

\section{Methods}

Diets, experimental design and animal husbandry

The experiment was approved by the University's Animal Ethics Committee (Authority No: AEC15-044) and conducted at the Animal House of the University of New England, Australia. The soybean grain was purchased from a local supplier in northern New South Wales, Australia. After cleaning and hammer-milling the grain to pass through a 2-mm sieve size, the meal was used to partially replace the commercial SBM at 0,15 or $25 \%$, equivalent to 0,45 and $75 \mathrm{~g} / \mathrm{kg}$ diet, respectively (Table 1). Birds were offered corn-soybean meal-based starter (0 to $10 \mathrm{~d}$ ), grower (10 to $24 \mathrm{~d}$ ) and finisher (24 to $35 \mathrm{~d}$ ) diets, which were formulated to the breeder standard for Ross 308 broilers [24]. The nutrient requirement of birds across the dietary treatment was balanced by supplementing with varying levels of canola oil, synthetic AA and the meat meal. The diets were supplemented with phytase (HiPhos) at 2000 phytase activity (FYT) $/ \mathrm{kg}$, equivalent to $0.2 \mathrm{~g} / \mathrm{kg}$ of diet, and fed as such or further supplemented with protease (ProAct) at $15000 \mathrm{PROT} / \mathrm{kg}$ (15,000 units of protease $/ \mathrm{kg}$ diet), the level approved by the European Food Safety Authority [25]. These enzymes were supplied by DSM Animal Nutrition, Asia-Pacific, Singapore. The microbial protease was added prior to pelleting the diets. Titanium dioxide was added to the grower diets to enable assessment of nutrient digestibility. Feed, in the form of crumble (starter) and pellet (grower and finisher periods) was provided ad libitum, and the birds had free access to water. Samples of the diets (with or without protease) were analyzed to evaluate the contents of $\mathrm{CP}$ and AA (Table 2).

A total of 336 Ross 308 male broiler chicks $(43.84 \pm 0.18 \mathrm{~g})$ were obtained from a local commercial hatchery (Baiada Poultry Pty. Ltd., Tamworth, Australia). These birds were randomly selected, weighed and randomly allocated into 42 pens at eight chicks per pen. This was a $2 \times 3$ factorial study, with each treatment being replicated six times and eight birds per replicate. Another lot of 48 birds, in six replicates, were fed on a nitrogen-free diet (NFD).

The six replicates were provided with the commercialtypes of starter and grower diets before they were transferred to the NFD diet, which was prepared without RFFS or microbial enzymes. The birds were raised in a climate-controlled room on sawdust litter.

On day 19, a total of 48 , with 8 birds per replicate were transferred to a nitrogen-free diet (NFD) to enable calculation of $\mathrm{CP}$ and AA flow at the ileum, and estimate standardized ileal digestibility (SID) of these nutrients.

Every pen was equipped with a clean feeder and two nipple drinkers that were daily checked and cleaned. The room temperature was set at $33{ }^{\circ} \mathrm{C}$ for the first two days, with a relative humidity of between 49 and $60 \%$. The temperature was gradually reduced to $24{ }^{\circ} \mathrm{C}$ at 19 days of age and was maintained for the remaining study period. Lighting was provided for $24 \mathrm{~h}(20 \mathrm{~lx})$ for 
Table 1 Ingredient and composition of starter, grower and finisher basal, and a nitrogen-free diet

\begin{tabular}{|c|c|c|c|c|c|c|c|c|c|c|}
\hline \multirow[t]{3}{*}{ Item } & \multirow{2}{*}{\multicolumn{3}{|c|}{$\begin{array}{l}\text { Starter } \\
\text { RFFS }^{1}, \mathrm{~g} / \mathrm{kg}\end{array}$}} & \multirow{2}{*}{\multicolumn{3}{|c|}{$\begin{array}{l}\text { Grower } \\
\text { RFFS }^{1}, \mathrm{~g} / \mathrm{kg}\end{array}$}} & \multirow{2}{*}{\multicolumn{3}{|c|}{$\begin{array}{l}\text { Finisher } \\
\text { RFFS }^{1}, \mathrm{~g} / \mathrm{kg}\end{array}$}} & \multirow[t]{3}{*}{ Nitrogen-free diet } \\
\hline & & & & & & & & & & \\
\hline & 0 & 45 & 75 & 0 & 45 & 75 & 0 & 45 & 75 & \\
\hline \multicolumn{11}{|l|}{ Ingredients (g/kg) } \\
\hline Corn (rolled) & 594.0 & 595.0 & 592.0 & 579.0 & 581.0 & 576.5 & 607.0 & 608.2 & 610.0 & 0.0 \\
\hline Corn starch & 0 & 0 & 0 & 0 & 0 & 0 & 0 & 0 & 0 & 433.0 \\
\hline Dextrose & 0 & 0 & 0 & 0 & 0 & 0 & 0 & 0 & 0 & 404.0 \\
\hline Soybean meal & 300 & 255 & 225 & 300 & 255 & 225 & 300.0 & 255.0 & 225.0 & 0.0 \\
\hline Raw soybean & 0 & 45 & 75 & 0 & 45 & 75 & 0 & 45.0 & 75.0 & 0 \\
\hline Canola oil & 16.0 & 9.4 & 7.9 & 45.6 & 40.5 & 40.3 & 51.1 & 46.3 & 43.5 & 50.0 \\
\hline Meat meal & 62.9 & 67.1 & 72.3 & 39.0 & 42.1 & 46.0 & 6.0 & 9.0 & 10.0 & 0.0 \\
\hline Cellulose & 0.0 & 0.0 & 0.0 & 0.0 & 0.0 & 0.0 & 0 & 0 & 0 & 50.0 \\
\hline Dicalcium phosphate & 7.7 & 8.0 & 7.6 & 9.5 & 11.0 & 11.0 & 15.8 & 15.5 & 15.5 & 25.7 \\
\hline $\mathrm{TiO}_{2}$ & 0 & 0 & 0 & 5.0 & 5.0 & 5.0 & 0 & 0 & 0 & 5.0 \\
\hline Limestone & 6.2 & 6.5 & 6.3 & 10.0 & 7.5 & 8.5 & 11.0 & 9.8 & 10.0 & 11.9 \\
\hline Salt & 3.0 & 3.0 & 3.0 & 2.3 & 2.0 & 2.3 & 2.2 & 2.1 & 2.1 & 0.0 \\
\hline L-lysine & 2.7 & 2.9 & 2.7 & 2.0 & 2.4 & 2.2 & 0.7 & 1.0 & 1.0 & 0.0 \\
\hline DL-methionine & 2.3 & 2.1 & 2.5 & 3.3 & 3.8 & 3.7 & 2.2 & 2.7 & 2.8 & 0.0 \\
\hline Premix ${ }^{2}(\mathrm{~g} / \mathrm{kg})$ & 2.0 & 2.0 & 2.0 & 2.0 & 2.0 & 2.0 & 2.0 & 2.0 & 2.0 & 2.0 \\
\hline L-threonine & 2.0 & 2.0 & 2.0 & 0.6 & 1.5 & 0.9 & 0.5 & 1.8 & 1.8 & 0.0 \\
\hline Sodium chloride & 0 & 0 & 0 & 0 & 0 & 0 & 0 & 0 & 0 & 2.5 \\
\hline Sodium bicarbonate & 1.4 & 1.6 & 1.4 & 1.1 & 1.0 & 0.9 & 1.0 & 1.0 & 1.0 & 1.9 \\
\hline Magnesium sulphate & 0 & 0 & 0 & 0 & 0 & 0 & 0 & 0 & 0 & 1.2 \\
\hline Potassium chloride & 0 & 0 & 0 & 0 & 0 & 0 & 0 & 0 & 0 & 9.0 \\
\hline Choline chloride & 0.5 & 0.5 & 0.5 & 1.0 & 0.5 & 0.8 & 0.5 & 0.5 & 0.5 & 3.5 \\
\hline Phytase (g/kg) & 0.20 & 0.20 & 0.20 & 0.20 & 0.20 & 0.20 & 0.20 & 0.20 & 0.20 & 0 \\
\hline \multicolumn{11}{|l|}{ Nutrients (g/kg) } \\
\hline Metabolizable energy (poultry; MJ/kg) & 12.59 & 12.59 & 12.59 & 13.28 & 13.28 & 13.28 & 13.49 & 13.49 & 13.49 & 14.44 \\
\hline Crude protein & 225.8 & 225.8 & 226.0 & 210.0 & 210.7 & 208.6 & 192.1 & 192.9 & 190.5 & $<6.0$ \\
\hline Crude fat & 42.1 & 39.8 & 44.6 & 68.7 & 67.7 & 73.6 & 68.8 & 70.7 & 71.9 & 0 \\
\hline Arginine & 14.4 & 14.3 & 14.4 & 13.4 & 13.3 & 13.3 & 12.3 & 12.3 & 12.1 & 0 \\
\hline Lysine & 14.0 & 14.0 & 14.0 & 12.7 & 12.7 & 12.8 & 10.5 & 10.7 & 10.6 & 0 \\
\hline Methionine & 5.7 & 5.2 & 5.7 & 6.5 & 6.7 & 6.6 & 5.0 & 5.4 & 5.4 & 0 \\
\hline Met + Cys & 8.8 & 8.3 & 8.8 & 9.4 & 9.7 & 9.6 & 7.9 & 8.3 & 8.3 & 0 \\
\hline Threonine & 9.9 & 9.4 & 9.9 & 8.2 & 8.9 & 8.3 & 7.4 & 8.7 & 8.6 & 0 \\
\hline Calcium & 10.0 & 10.3 & 10.0 & 9.9 & 9.4 & 9.8 & 8.7 & 8.5 & 8.5 & 10.0 \\
\hline Available phosphorus & 5.0 & 5.1 & 5.0 & 4.4 & 4.6 & 4.6 & 4.2 & 4.3 & 4.2 & 4.8 \\
\hline Choline & 1.4 & 1.4 & 1.4 & 1.5 & 1.3 & 1.4 & 1.4 & 1.3 & 1.2 & 1.5 \\
\hline
\end{tabular}

${ }^{2}$ Premix (g/kg of feed): Cu, 8 mg; Fe, 60 mg; l, 1.0 mg; Se, 0.3 mg; Mn, 80 m g; Zn, 60 mg; Mo, 1 mg; Co, 0.3 vitamin A, 12 MIU; Vitamin D 3.3 MIU; Vitamin E, $40 \mathrm{~g}$, Vitamin $\mathrm{K}_{3}, 2 \mathrm{mg}$; thiamine, $2 \mathrm{mg}$; riboflavin $\left(\mathrm{B}_{2}\right), 6 \mathrm{mg}$; niacin $\left(\mathrm{B}_{2}\right), 50 \mathrm{mg}$; pantothenate, $11 \mathrm{mg} ;$ pyridoxine, $20 \mathrm{mg}$; folate, $0.0015 \mathrm{mg}$; Biotin, $100 \mathrm{mg}$; Vitamin $B_{12}, 0.02 \mathrm{mg}$; Vitamin $B_{6} ; 1.5$ mg; biotin, 0.01 mg; Antioxidant, 25 mg. ${ }^{1} \mathrm{RFFS}=$ raw full-fat soybean. SBM = commercial soybean meal. Basal diets were prepared when the SBM was replaced by RFFS at 0, 15 and $25 \%$, equivalent to 0,45 and $75 \mathrm{~g} / \mathrm{kg}$ of diet, respectively)

Microbial protease was then supplemented to the basal diets ( 0 or 15,000 PROT/kg of diet). A 15000 PROT/kg $=15,000$ units of protease/kg of diet, equivalent to $200 \mathrm{mg}$ of protease/kg of diet. The 3 experimental periods of this study were starter (day 0 to 10), grower (day 10 to 24 ) and finisher (day 24 to 32 ). FYT = FTU as a unit that measuring the releasing capacity of nutrient by microbial phytase. NFD = nitrogen free diet 
Table 2 The analysed crude protein (CP) and amino acid composition $(\mathrm{g} / \mathrm{kg})$ of the study diets fed in days of 10 to 24

\begin{tabular}{|c|c|c|c|c|c|c|c|}
\hline \multirow{2}{*}{$\begin{array}{l}\text { Protease (PROT/kg) } \\
\text { RFFS }^{1}(\mathrm{~g} / \mathrm{kg})\end{array}$} & \multicolumn{3}{|l|}{0} & \multicolumn{3}{|c|}{15,000} & \multirow{2}{*}{$\begin{array}{l}\text { Nitrogen-free diet } \\
0\end{array}$} \\
\hline & $\overline{0}$ & 45 & 75 & $\overline{0}$ & 45 & 75 & \\
\hline Crude protein & 224 & 219 & 222 & 224 & 221 & 217 & $<6.0$ \\
\hline \multicolumn{8}{|c|}{ Indispensable amino acids } \\
\hline His & 5.5 & 5.3 & 5.5 & 5.5 & 5.4 & 5.2 & $<0.1$ \\
\hline $\operatorname{Arg}$ & 14.3 & 14.2 & 14.4 & 14.1 & 14.4 & 13.0 & $<0.4$ \\
\hline Thr & 8.7 & 8.4 & 8.8 & 9.2 & 9.2 & 8.4 & $<0.2$ \\
\hline Lys & 12.8 & 12.3 & 13.4 & 12.8 & 13.3 & 11.9 & $<0.3$ \\
\hline Met & 5.1 & 4.7 & 5.2 & 5.8 & 5.3 & 5.0 & $<0.1$ \\
\hline Val & 10.7 & 10.2 & 10.7 & 10.5 & 10.4 & 10.0 & $<0.3$ \\
\hline lle & 9.0 & 8.7 & 9.1 & 8.8 & 8.8 & 8.2 & $<0.2$ \\
\hline Leu & 18.0 & 17.6 & 18.1 & 17.9 & 18.0 & 17.9 & $<0.5$ \\
\hline Phe & 10.4 & 10.1 & 10.4 & 10.3 & 10.3 & 9.8 & $<0.3$ \\
\hline \multicolumn{8}{|c|}{ Dispensable amino acids } \\
\hline Ser & 10.6 & 10.4 & 10.6 & 10.5 & 10.5 & 10.1 & $<0.3$ \\
\hline Gly & 11.4 & 12.4 & 11.4 & 10.6 & 11.1 & 10.4 & $<0.3$ \\
\hline Asp & 20.3 & 20.1 & 20.7 & 19.8 & 20.4 & 19.0 & $<0.5$ \\
\hline Glu & 37.2 & 37.0 & 37.8 & 36.8 & 37.6 & 36.2 & $<1.0$ \\
\hline Ala & 11.0 & 11.2 & 11.0 & 10.7 & 10.9 & 10.8 & $<0.3$ \\
\hline Pro & 13.6 & 14.0 & 13.6 & 13.3 & 13.5 & 13.2 & $<0.4$ \\
\hline Tyr & 4.9 & 5.0 & 5.2 & 5.0 & 5.1 & 4.4 & $<0.1$ \\
\hline
\end{tabular}

${ }^{1}$ RFFS = raw full-fat soybean (SBM was replaced by RFFS at zero, 15 and 25\%, equivalent to zero, 45 and $75 \mathrm{~g} / \mathrm{kg}$ of diet, respectively). A 15000 PROT/ $\mathrm{kg}=15,000$ units of protease $/ \mathrm{kg}$ of diet, equivalent to $200 \mathrm{mg}$ of protease / $\mathrm{kg}$ of diet

the first two days, then reduced to $23 \mathrm{~h}$ for the next 6 consecutive days, followed by 20 -h light (10 lx) for the remaining days. Mortality of birds was recorded whenever it occurred.

\section{Data collection}

On days 10, 24 and 35, the body weight of birds and feed leftover were recorded, to calculate the body weight gain (BWG) and feed intake (FI), from which the feed conversion ratio (FCR) was computed. On day 24, at least two birds per replicate were euthanised by cervical dislocation and excised. Ileal digesta were collected on ice, pooled per replicate, and then transferred to a freezer $\left(-20{ }^{\circ} \mathrm{C}\right)$ until they were analyzed for nutrient composition. Except for birds on NFD, samples of internal organs were also collected at day 24 and weighed. One representative bird per cage was randomly selected, electrically stunned and killed by cervical dislocation. The bird was dissected to obtain internal organs, which were weighed as described by [26]. The remaining birds, (except those allocated to the NFD) were transferred to finisher diets and raised to 35 day of age, with the aim of evaluating the growth performance.
Chemical analysis and calculation of nutrient digestibility Sub-samples of the ingredients and test diets were analysed for CP and AA [27, 28], urease activity (UA) [29], nitrogen solubility index (NSI) [30], contents of TI (TIU/g) [31], protein solubility [32], starch [33], total sugars [33], ether extract [34] and crude fiber [35].

According to Cohen and Michaud [36, 37], amino acid contents of ingredients, diets and digesta were analyzed by the Australian Proteome Analysis Facility, Macquarie University, Australia. Amino acid (AA) concentrations were determined using pre-column derivatization AA analysis with 6-aminoquinolyl- $N$-hydroxysuccinimidyl carbamate followed by separation of the derivatives and quantification by reversed phase high performance liquid chromatography.

The concentration of titanium ( $\mathrm{Ti}$ ) in the ileal digesta and diets was determined using the method described by Short et al. [38]. The data on concentrations of nutrients and the $\mathrm{Ti}$ marker were used in the following calculations.

Ileal AA outflow (IAAF; mg/g intake) and ileal CP outflow (ICPF; $\mathrm{mg} / \mathrm{g}$ intake) for all treatments (including NFD) were determined against the $\mathrm{Ti}$ concentration as follows: 
IAAF or $\mathrm{ICPF}=\mathrm{AA}$ or $\mathrm{CP}$ in digesta $(\mathrm{mg} / \mathrm{g}) /[\mathrm{Ti}$ in $\operatorname{diet}(\mathrm{mg} / \mathrm{g}) / \mathrm{Ti}$ in $\operatorname{digesta}(\mathrm{mg} / \mathrm{g})$ ].

The coefficient of apparent ileal digestibility (AID) and the coefficient of standardized ileal digestibility (SID) of CP and AA were calculated using the following equations:

$$
\begin{aligned}
\mathrm{AID}= & (\text { diet AA or CP intake-IAAF or ICPF }) \\
& / \text { Diet AA or CP intake. } \\
\text { SID = } & (\text { diet AA or CP intake-[IAAF or ICPF } \\
& - \text { EIAAF or ECPF] }) / \text { Diet AA, or CP intake }
\end{aligned}
$$

where, EIAAF is the endogenous ileal amino acid flow, and ECPF is the endogenous crude protein flow calculated using Eq. 1 from the ileal digesta of chicks fed NFD.

\section{Statistical analysis}

One-way ANOVA and general linear model (GLM) of Minitab software version 17 [39], were used to analyse the data. The effects of the main factors (RFFS level and enzyme supplementation as well as their interactions) were assessed. Differences between the mean values were separated by the Duncan's multiple range tests and were considered to be significant at $P \leq 0.05$.

\section{Results}

\section{Response to the diets}

The nutrient composition and quality measures for RFFS and SBM were different (Table 3). For examples, both the ether extracts $(147.3 \mathrm{~g} / \mathrm{kg})$ and $\mathrm{ME} / \mathrm{kg}(12.6 \mathrm{MJ}$ $\mathrm{ME} / \mathrm{kg}$ ) contents of RFFS were higher than those of $\mathrm{SBM}$, which were $19.2 \mathrm{~g} / \mathrm{kg}$ and $9.0 \mathrm{MJ} \mathrm{ME} / \mathrm{kg}$; the reverse was the case for AA profile while the concentrations of TI and UA were lower in SBM than in the RFFS. Replacing the commercial SBM by RFFS from 0 to $75 \mathrm{~g} / \mathrm{kg}$ diet resulted in an increase in selected ANF in the diets (Table 4). The TI concentration was increased from 1747.0 to $10,193.4 \mathrm{TIU} / \mathrm{g}$; the NSI increased from 155.3 to $222.9 \mathrm{~g} / \mathrm{kg}$, and the UA was raised from 0.16 to $1.53 \Delta \mathrm{pH}$.

The performance of the birds, in terms of FI, BWG and FCR are presented in Table 5. There were no significant $(P>0.05)$ interaction effects between RFFS and protease on the FI, BWG or FCR of birds during any of the assessed periods.

The feed intake of birds was reduced with increase in RFFS inclusion in the diets, particularly affecting birds over the longer rearing period (day 0 to 35$)(P<0.05)$. Application of protease in these diets appeared not to influence $(P>0.05)$ the feed consumption. The FI was generally reduced $(P<0.05)$ during day 0 to 35 because of increasing inclusion of dietary RFFS in diets. The BWG was also decreased during day 0 to10 $(P<0.01)$, day 0 to $24(P<0.05)$ and day 0 to $35(P<0.05)$.

However, protease supplementation improved $(P<0.05)$ both the BWG and the FCR of birds during the day 0 to 24. Increasing the level of RFFS in diets (without protease supplementation) reduced the feed efficiency by $2.94 \%$, whereas due to supplementation with microbial protease numerically improved the feed efficiency by $3.30 \%$. However, these slight improvements were not statistically significant $(P>0.05)$. There were no significant $(P>0.05)$ effects of treatment on mortality.

\section{Visceral organ weights}

As shown in Table 6, the RFFS by protease interaction had no significant $(P>0.05)$ effects on the weight of any of the internal organs assessed at $d 24$. Increasing the RFFS inclusion rate in diets significantly increased the weight of the gizzard and proventriculus $(P<0.001)$, pancreas $(P<0.001)$, small intestine (jejunum + ileum + duodenum $)(P<0.001)$, heart $(P<0.001)$ and spleen $(P<0.05)$. The weight of the bursa also tended $(P=0.09)$ to increase at day 24 . Protease supplementation significantly increased $(P=0.05)$ bursa weight but had no significant $(P>0.05)$ effects on any of the other

\begin{tabular}{|c|c|c|c|c|c|c|c|c|c|c|c|c|c|c|c|c|}
\hline \multirow{2}{*}{$\begin{array}{l}\text { Item } \\
\text { Dry m }\end{array}$} & \multicolumn{8}{|c|}{ Nutrient composition (g/kg) } & \multicolumn{8}{|c|}{ Quality parameters (g/kg) } \\
\hline & hatter & Crude fibre & Crude protein & Ether extracts & Total Sugars & Starch & \multicolumn{2}{|c|}{$\begin{array}{l}\mathrm{ME} \\
\mathrm{MJ} / \mathrm{kg}\end{array}$} & \multicolumn{2}{|c|}{$\begin{array}{l}\text { Available } \\
\text { lysine }\end{array}$} & $\mathrm{KOH}$ & \multicolumn{2}{|c|}{$\begin{array}{l}\text { Trypsin inhibitors, } \\
\text { TIU/g }\end{array}$} & \multicolumn{3}{|c|}{$\begin{array}{l}\text { Urease } \\
\text { activity } \Delta \mathrm{pH}\end{array}$} \\
\hline RFFS & 923.6 & 62.0 & 382.4 & 147.3 & 95.0 & 26.1 & 12.6 & & 26.4 & & 898.6 & 13,498 & & 2.1 & & \\
\hline \multirow[t]{3}{*}{ SBM } & 914.8 & 37.9 & 422.9 & 19.2 & 107.6 & 37.0 & 9.0 & & 28.4 & & 794.4 & 5743 & & 0.09 & & \\
\hline & \multicolumn{8}{|c|}{ Indispensable amino acids } & & & \multicolumn{6}{|c|}{ Dispensable amino acids } \\
\hline & Met & Lys & Iso & Leu & Cys & Thr & His & Try & Arg & Val & Ala & Ser & Gly & Try ASP & Glu & Pro \\
\hline RFFS & 5.6 & 26.6 & 17.9 & 31.0 & 6.0 & 16.1 & 10.9 & 4.7 & 32.9 & 18.7 & 17.3 & 19.4 & 17.3 & $4.7 \quad 45.8$ & 73.3 & 20.2 \\
\hline SBM & 6.2 & 29.0 & 20.5 & 35.6 & 6.0 & 18.2 & 12.1 & 6.5 & 32.9 & 21.9 & 20.3 & 20.2 & 19.5 & $6.5 \quad 51.0$ & 82.5 & 22.7 \\
\hline
\end{tabular}
measured internal organs.

Table 3 Analysed nutrient composition and quality parameters of raw soybean meal (RFFS) in comparison to the commercial soybean meal (SBM) 
Table 4 Effects of partially replacing commercial SBM by RFFS on quality of the diets

\begin{tabular}{llll}
\hline & \multicolumn{3}{l}{ RFFS (g/kg of diet) } \\
\cline { 2 - 4 } & 0 & 45 & 75 \\
\hline Available lysine, g/kg & 16.2 & 15.2 & 15.45 \\
Nitrogen solubility, g/kg & 155.3 & 187.6 & 222.9 \\
Trypsin inhibitor $(\mathrm{TIU} / \mathrm{g})$ & 1747 & 7897 & 10,194 \\
Urease activity $(\Delta \mathrm{pH})$ & 0.16 & 1.00 & 1.525 \\
\hline
\end{tabular}

\section{Ileal digestibility of crude protein and amino acids.}

The results revealed that basal endogenous loss of ileal CP was significantly $(P<0.001)$ increased in response to rising the level of RFFS. On average, the basal endogenous loss of ileal AA, except that of methionine at day 24 was significantly increased in birds fed diets containing RFFS (Table 7).

At day $24 \mathrm{~d}$, increasing the RFFS inclusion rate significantly reduced $(P<0.01)$ the values of AID and SID for $\mathrm{CP}$, and it also reduced the value of AID and SID of indispensable AA by up to 8.5 and $7.7 \%$, respectively, with the lowest value for methionine and the highest for isoleucine. The AID and SID values of dispensable AA were also reduced by between 5.0 to 8.0 and 4.0 to $7.0 \%$, respectively in line with increase in RFFS (Tables 8 and 9).
Under microbial protease supplementation, the basal endogenous loss of ileal CP and total AA were reduced by approximately 7.0 and $3.5 \%$, respectively, but the differences were not significant $(P>0.05)$. The AID and SID of CP measured at day 24 were significantly $(P<0.05)$ increased when the diets were supplemented with microbial protease, and they were also significantly $(P<0.05)$ influenced by the interaction effects between protease and RFFS. Protease supplementation had the reverse effect on the AID and SID of CP, resulting into a lack of interaction between the two main factors.

Although statistically the same $(P>0.05)$, the average basal endogenous loss of indispensable and dispensable AA at the ileum, were reduced by approximately 4.5 and $2.0 \%$, respectively when the diets were supplemented with protease. However, supplementation with protease resulted in an increase in the AID and SID values of indispensable AA, which respectively ranged between 0 and $2.0 \%$ and 0 and $1.5 \%$ more than the non-supplemented diets, but the differences were not statistically significant $(P>0.05)$. Although the differences were not significant $(P>0.05)$, the average AID and SID values of dispensable AA at day 24 were $0.78 \%$ and $0.56 \%$, respectively greater when the diets were supplemented with microbial protease. The AID $(P<0.5)$ and SID

Table 5 Effects of protease in diets with raw soybean on Fl, BWG (g/b) and FCR, in periods of day 0 to 10 , day 0 to 24 or day 0 to 35

\begin{tabular}{|c|c|c|c|c|c|c|c|c|c|c|}
\hline \multirow{2}{*}{$\begin{array}{l}\mathrm{RFFS}^{1} \\
\mathrm{~g} / \mathrm{kg}\end{array}$} & \multirow{2}{*}{$\begin{array}{l}\text { Protease } \\
\text { PROT/kg }\end{array}$} & \multicolumn{3}{|c|}{ Feed intake } & \multicolumn{3}{|c|}{ Body weight gain } & \multicolumn{3}{|l|}{ FCR } \\
\hline & & $0-10$ & $0-24$ & $0-35$ & $0-10$ & $0-24$ & $0-35$ & $0-10$ & $0-24$ & $0-35$ \\
\hline \multirow[t]{2}{*}{0} & 0 & 315.7 & 1774 & 3608 & 290.4 & 1364 & 2626 & 1.09 & 1.28 & 1.36 \\
\hline & 15,000 & 317.1 & 1804 & 3552 & 296.5 & 1470 & 2631 & 1.07 & 1.23 & 1.35 \\
\hline \multirow[t]{2}{*}{45} & 0 & 294.2 & 1724 & 3425 & 279.4 & 1335 & 2566 & 1.05 & 1.29 & 1.39 \\
\hline & 15,000 & 306.1 & 1663 & 3322 & 274.9 & 1402 & 2537 & 1.12 & 1.22 & 1.34 \\
\hline \multirow[t]{2}{*}{75} & 0 & 294.3 & 1735 & 3426 & 266.3 & 1330 & 2444 & 1.12 & 1.31 & 1.43 \\
\hline & 15,000 & 291.2 & 1708 & 3481 & 264.6 & 1376 & 2516 & 1.10 & 1.24 & 1.35 \\
\hline \multicolumn{2}{|l|}{ SEM } & 4.3 & 22.2 & 37.5 & 3.8 & 16.7 & 28.5 & 0.02 & 0.01 & 0.02 \\
\hline \multicolumn{11}{|c|}{ Main effects } \\
\hline \multicolumn{2}{|l|}{0} & 316.4 & 1789 & $3580^{a}$ & $293.5^{\mathrm{a}}$ & $1417^{\mathrm{a}}$ & $2629^{a}$ & 1.079 & 1.26 & 1.35 \\
\hline \multicolumn{2}{|l|}{45} & 300.1 & 1693 & $3456^{b}$ & $277.2^{\mathrm{ab}}$ & $1369^{b}$ & $2550^{\mathrm{ab}}$ & 1.084 & 1.24 & 1.36 \\
\hline \multirow[t]{3}{*}{75} & & 292.7 & 1707 & $3378^{b}$ & $265.5^{b}$ & $1338^{b}$ & $2473^{b}$ & 1.109 & 1.27 & 1.39 \\
\hline & 0 & 301.4 & 1744 & 3490 & 278.7 & $1343^{b}$ & 2539 & 1.087 & $1.28^{\mathrm{a}}$ & 1.39 \\
\hline & 15,000 & 304.8 & 1716 & 3459 & 278.7 & $1406^{a}$ & 2563 & 1.095 & $1.23^{b}$ & 1.35 \\
\hline \multicolumn{11}{|c|}{ Sources of variation } \\
\hline \multicolumn{2}{|c|}{ RFFS } & 0.08 & NS & * & ** & * & * & NS & NS & NS \\
\hline \multicolumn{2}{|c|}{ Protease } & NS & NS & NS & NS & $*$ & NS & NS & * & NS \\
\hline \multicolumn{2}{|c|}{ RFFS $\times$ protease } & NS & NS & NS & NS & NS & NS & NS & NS & NS \\
\hline
\end{tabular}

${ }^{\mathrm{a}, \mathrm{b}}$ Means bearing uncommon superscripts within a column are significantly different at NS = non-significant; ${ }^{*} P<0.05 ;{ }^{* *} P<0.01 ; \mathrm{FI}=$ feed intake; $\mathrm{BWG}=$ body weight gain; FCR = feed conversion ratio; ${ }^{1}$ RFFS = raw full-fat soybean (SBM was replaced by RFFS at zero, 15 and $25 \%$, equivalent to zero, 45 and $75 \mathrm{~g} / \mathrm{kg}$ of diet, respectively); SEM = standard error of means. A $15000 \mathrm{PROT} / \mathrm{kg}=15,000$ units of protease $/ \mathrm{kg}$ of diet, equivalent to $200 \mathrm{mg}$ of protease/kg of diet 
Table 6 Effects of supplemental protease in diets containing graded levels of raw soybean on the weights of internal organs (g/ $100 \mathrm{~g}$ body weight) at day 24

\begin{tabular}{|c|c|c|c|c|c|c|c|c|}
\hline $\mathrm{RFFS}^{1}, \mathrm{~g} / \mathrm{kg}$ & Protease, PROT/kg & $G+P$ & Pancreas & $\mathrm{SI}$ & Heart & Liver & Bursa & Spleen \\
\hline \multirow[t]{2}{*}{$\overline{0}$} & 0 & 2.74 & 0.21 & 4.04 & 0.58 & 2.49 & 0.19 & 0.08 \\
\hline & 15,000 & 2.79 & 0.21 & 4.02 & 0.54 & 2.66 & 0.20 & 0.08 \\
\hline \multirow[t]{2}{*}{45} & 0 & 3.72 & 0.36 & 5.43 & 0.69 & 3.07 & 0.20 & 0.12 \\
\hline & 15,000 & 3.58 & 0.35 & 5.77 & 0.74 & 2.76 & 0.28 & 0.10 \\
\hline \multirow[t]{2}{*}{75} & 0 & 3.40 & 0.37 & 4.97 & 0.66 & 2.58 & 0.18 & 0.09 \\
\hline & 15,000 & 3.31 & 0.35 & 4.71 & 0.64 & 2.87 & 0.20 & 0.08 \\
\hline \multicolumn{2}{|l|}{ SEM } & 0.10 & 0.02 & 0.19 & 0.02 & 0.09 & 0.01 & 0.01 \\
\hline \multicolumn{9}{|l|}{ Main effects } \\
\hline \multicolumn{2}{|l|}{0} & $2.77^{c}$ & $0.21^{b}$ & $4.03^{b}$ & $0.56^{c}$ & 2.58 & 0.20 & $0.08^{b}$ \\
\hline \multicolumn{2}{|l|}{45} & $3.65^{\mathrm{a}}$ & $0.35^{\mathrm{a}}$ & $5.57^{\mathrm{a}}$ & $0.71^{\mathrm{a}}$ & 2.91 & 0.24 & $0.11^{\mathrm{a}}$ \\
\hline \multirow[t]{3}{*}{75} & & $3.36^{\mathrm{b}}$ & $0.36^{\mathrm{a}}$ & $4.84^{\mathrm{a}}$ & $0.65^{\mathrm{b}}$ & 2.73 & 0.19 & $0.08^{b}$ \\
\hline & 0 & 3.29 & 0.31 & 4.81 & 0.64 & 2.7 & $0.19^{\mathrm{b}}$ & 0.09 \\
\hline & 15,000 & 3.23 & 0.30 & 4.71 & 0.64 & 2.8 & $0.23^{\mathrm{a}}$ & 0.09 \\
\hline \multicolumn{9}{|c|}{ Sources of variation } \\
\hline \multicolumn{2}{|l|}{ RFFS } & $* * *$ & $* * *$ & $* * *$ & $* * *$ & NS & NS & * \\
\hline \multicolumn{2}{|l|}{ Protease } & NS & NS & NS & NS & NS & * & NS \\
\hline \multicolumn{2}{|c|}{ RFFS $\times$ protease } & NS & NS & NS & NS & NS & NS & NS \\
\hline
\end{tabular}

a,b,c Means bearing uncommon superscripts within a column are significantly different at NS = non-significant; ${ }^{* * *} P<0.001 ;{ }^{*} P<0.05 ;{ }^{1} \mathrm{RFFS}=$ raw full-fat soybean (SBM was replaced by RFFS at zero, 15 and 25\%, equivalent to zero, 45 and $75 \mathrm{~g} / \mathrm{kg}$ of diet, respectively); SEM = standard error of means; SI = Small intestine (jejunum, ileum and duodenum) were weighed with the contents; G + P (gizzard and proventriculus) were weighed with the contents; SEM = Pooled standard error of mean. A 15000 PROT/ $\mathrm{kg}=15,000$ units of protease $/ \mathrm{kg}$ of diet, equivalent to $200 \mathrm{mg}$ of protease/ $\mathrm{kg}$ of diet

Table 7 Effects of protease supplementation of diets containing raw soybean on the ileal flow ( $\mathrm{g} / \mathrm{kg}$ of Fl) of undigested crude protein and amino acids ( $\mathrm{mg} / \mathrm{g})$ at day 24

\begin{tabular}{|c|c|c|c|c|c|c|c|c|c|c|c|c|c|c|c|}
\hline \multirow{2}{*}{$\begin{array}{l}\text { RFFS }^{1} \\
(\mathrm{~g} / \mathrm{kg})\end{array}$} & \multirow{2}{*}{$\begin{array}{l}\text { Protease } \\
\text { (PROT/kg) }\end{array}$} & \multirow[t]{2}{*}{$\mathrm{CP}$} & \multicolumn{9}{|c|}{ Indispensable amino acids } & \multicolumn{4}{|c|}{ Dispensable amino acids } \\
\hline & & & His & Arg & Thr & Lys & Met & Val & Ile & Leu & Phe & Ser & Gly & Ala & Pro \\
\hline \multirow[t]{2}{*}{0} & 0 & 41.30 & 0.96 & 1.47 & 2.06 & 1.97 & 0.28 & 2.32 & 1.86 & 3.30 & 1.89 & 2.26 & 2.94 & 2.21 & 2.82 \\
\hline & 15,000 & 38.50 & 0.87 & 1.40 & 1.95 & 1.75 & 0.24 & 2.05 & 1.65 & 2.88 & 1.67 & 2.11 & 2.82 & 1.96 & 2.63 \\
\hline \multirow[t]{2}{*}{45} & 0 & 43.60 & 1.01 & 1.56 & 2.22 & 2.09 & 0.26 & 2.47 & 2.02 & 3.52 & 2.03 & 2.49 & 3.03 & 2.34 & 2.99 \\
\hline & 15,000 & 40.60 & 1.02 & 1.56 & 2.23 & 2.03 & 0.30 & 2.46 & 1.99 & 3.50 & 1.97 & 2.49 & 3.02 & 2.29 & 2.93 \\
\hline \multirow[t]{2}{*}{75} & 0 & 65.30 & 1.12 & 1.82 & 2.36 & 2.33 & 0.31 & 2.78 & 2.30 & 3.99 & 2.28 & 2.71 & 3.26 & 2.53 & 3.11 \\
\hline & 15,000 & 55.60 & 1.09 & 1.70 & 2.35 & 2.15 & 0.30 & 2.68 & 2.20 & 3.90 & 2.16 & 2.65 & 3.24 & 2.51 & 3.16 \\
\hline \multicolumn{2}{|l|}{ SEM } & 0.9 & 0.02 & 0.05 & 0.04 & 0.05 & 0.01 & 0.06 & 0.05 & 0.10 & 0.05 & 0.05 & 0.04 & 0.06 & 0.06 \\
\hline \multicolumn{16}{|c|}{ Main effects } \\
\hline \multicolumn{2}{|l|}{0} & $39.90^{b}$ & $0.92^{b}$ & $1.43^{b}$ & $2.01^{b}$ & $1.86^{\mathrm{b}}$ & 0.26 & $2.19^{c}$ & $1.75^{c}$ & $3.09^{c}$ & $1.78^{\mathrm{C}}$ & $2.18^{b}$ & $2.88^{b}$ & $2.09^{b}$ & $2.72^{b}$ \\
\hline \multicolumn{2}{|l|}{45} & $42.10^{b}$ & $1.01^{b}$ & $1.56^{\mathrm{a}}$ & $2.22^{a}$ & $2.06^{a}$ & 0.28 & $2.46^{b}$ & $2.01^{b}$ & $3.51^{b}$ & $2.00^{\mathrm{b}}$ & $2.49^{a}$ & $3.03^{b}$ & $2.32^{\mathrm{ab}}$ & $2.96^{a b}$ \\
\hline \multicolumn{2}{|l|}{45} & $60.50^{a}$ & $1.10^{\mathrm{a}}$ & $1.76^{\mathrm{a}}$ & $2.35^{\mathrm{a}}$ & $2.24^{a}$ & 0.30 & $2.73^{\mathrm{a}}$ & $2.25^{\mathrm{a}}$ & $3.94^{\mathrm{a}}$ & $2.22^{a}$ & $2.68^{a}$ & $3.25^{\mathrm{a}}$ & $2.52^{a}$ & $3.14^{\mathrm{a}}$ \\
\hline & 0 & 49.10 & 1.03 & 1.61 & 2.22 & 2.11 & 0.29 & 2.52 & 2.05 & 3.60 & 2.05 & 2.48 & 3.07 & 2.34 & 2.95 \\
\hline & 15,000 & 45.90 & 0.99 & 1.55 & 2.17 & 2.00 & 0.27 & 2.40 & 1.96 & 3.43 & 1.95 & 2.42 & 3.03 & 2.27 & 2.93 \\
\hline \multicolumn{16}{|c|}{ Sources of variation } \\
\hline \multicolumn{2}{|c|}{ RFFS } & $* * *$ & $* *$ & * & ** & $* *$ & NS & $* * *$ & $* * *$ & $* * *$ & $* * *$ & $* * *$ & $* * *$ & $* *$ & $* *$ \\
\hline \multicolumn{2}{|c|}{ Protease } & NS & NS & NS & NS & NS & NS & NS & NS & NS & NS & NS & NS & NS & NS \\
\hline \multicolumn{2}{|c|}{ RFFS $\times$ protease } & NS & NS & NS & NS & NS & NS & NS & NS & NS & NS & NS & NS & NS & NS \\
\hline
\end{tabular}

a,b,c Means bearing uncommon superscript within a column are significantly different at NS = non-significant; ${ }^{*} P<0.05 ;{ }^{* *} P<0.01 ;{ }^{* * *} P<0.001 ;{ }^{1} \mathrm{RFFS}=$ raw full-fat soybean (SBM was replaced by RFFS at zero, 15 and 25\%, equivalent to zero, 45 and $75 \mathrm{~g} / \mathrm{kg}$ of diet, respectively); SEM = standard error of means. A 15000 PROT/ $\mathrm{kg}=15,000$ units of protease $/ \mathrm{kg}$ of diet, equivalent to $200 \mathrm{mg}$ of protease / $\mathrm{kg}$ of diet 
Table 8 Effects of protease and RFFS supplementations on the coefficient of apparent ileal digestibility of CP and AA of broilers at day 24

\begin{tabular}{|c|c|c|c|c|c|c|c|c|c|c|c|c|c|c|c|}
\hline \multirow{2}{*}{$\begin{array}{l}\text { RFFS } \\
(\mathrm{g} / \mathrm{kg})\end{array}$} & \multirow{2}{*}{$\begin{array}{l}\text { Protease } \\
\text { (PROT/kg) }\end{array}$} & \multirow[t]{2}{*}{$\mathrm{CP}$} & \multicolumn{9}{|c|}{ Indispensable amino acids } & \multicolumn{4}{|c|}{ Dispensable amino acids } \\
\hline & & & $\mathrm{His}$ & Arg & Thr & Lys & Met & Val & Ile & Leu & Phe & $\overline{\text { Ser }}$ & Gly & Ala & Pro \\
\hline \multirow[t]{2}{*}{0} & 00 & $0.775^{\mathrm{b}}$ & 0.818 & 0.905 & 0.762 & $0.848^{\mathrm{a}}$ & 0.945 & 0.786 & 0.800 & 0.824 & 0.825 & 0.793 & 0.770 & 0.815 & 0.806 \\
\hline & 15,000 & $0.812^{\mathrm{a}}$ & 0.841 & 0.894 & 0.772 & $0.859^{\mathrm{a}}$ & 0.948 & 0.802 & 0.809 & 0.832 & 0.832 & 0.794 & 0.748 & 0.815 & 0.801 \\
\hline \multirow[t]{2}{*}{45} & 0 & $0.783^{\mathrm{ab}}$ & 0.815 & 0.888 & 0.755 & $0.838^{\mathrm{ab}}$ & 0.946 & 0.762 & 0.771 & 0.801 & 0.807 & 0.761 & 0.712 & 0.779 & 0.777 \\
\hline & 15,000 & $0.772^{\mathrm{b}}$ & 0.816 & 0.891 & 0.754 & $0.848^{\mathrm{a}}$ & 0.952 & 0.774 & 0.782 & 0.810 & 0.808 & 0.771 & 0.737 & 0.792 & 0.784 \\
\hline \multirow[t]{2}{*}{75} & 0 & $0.757^{\mathrm{b}}$ & 0.785 & 0.867 & 0.721 & $0.810^{\mathrm{b}}$ & 0.941 & 0.727 & 0.724 & 0.780 & 0.773 & 0.737 & 0.692 & 0.768 & 0.766 \\
\hline & 15,000 & $0.776^{b}$ & 0.799 & 0.880 & 0.744 & $0.837^{\mathrm{ab}}$ & 0.943 & 0.743 & 0.750 & 0.784 & 0.789 & 0.745 & 0.706 & 0.771 & 0.765 \\
\hline \multicolumn{2}{|l|}{ SEM } & 0.004 & $0 . .04$ & 0.004 & 0.04 & 0.004 & 0.02 & 0.006 & 0.007 & 0.006 & 0.005 & 0.005 & 0.006 & 0.005 & 0.005 \\
\hline \multicolumn{16}{|c|}{ Main effects } \\
\hline \multicolumn{2}{|l|}{0} & 0.794 & $0.830^{a}$ & $0.899^{a}$ & $0.767^{a}$ & 0.854 & 0.946 & $0.794^{a}$ & $0.805^{a}$ & $0.828^{a}$ & $0.828^{a}$ & $0.793^{a}$ & $0.759^{a}$ & $0.815^{a}$ & $0.804^{a}$ \\
\hline \multicolumn{2}{|l|}{45} & 0.778 & $0.816^{b}$ & $0.889^{a b}$ & $0.755^{\mathrm{ab}}$ & 0.843 & 0.949 & $0.768^{b}$ & $0.777^{b}$ & $0.805^{\mathrm{ab}}$ & $0.807^{\mathrm{ab}}$ & $0.766^{b}$ & $0.725^{b}$ & $0.785^{b}$ & $0.781^{b}$ \\
\hline \multicolumn{2}{|l|}{75} & 0.766 & $0.792^{b}$ & $0.874 b$ & $0.733^{b}$ & 0.823 & 0.942 & $0.735^{c}$ & $0.737^{c}$ & $0.782^{b}$ & $0.781^{b}$ & $0.741^{c}$ & $0.699^{c}$ & $0.769^{c}$ & $0.765^{c}$ \\
\hline & 0 & 0.772 & 0.806 & 0.887 & 0.746 & 0.832 & 0.944 & 0.758 & 0.765 & 0.802 & 0.802 & 0.764 & 0.725 & 0.787 & 0.783 \\
\hline & 15,000 & 0.786 & 0.819 & 0.888 & 0.757 & 0.848 & 0.948 & 0.773 & 0.781 & 0.808 & 0.809 & 0.770 & 0.730 & 0.793 & 0.783 \\
\hline \multicolumn{16}{|c|}{ Sources of variation } \\
\hline \multicolumn{2}{|c|}{ RFFS } & $* *$ & $* * *$ & $* *$ & $* * *$ & $* *$ & NS & $* * *$ & $* * *$ & $* * *$ & $* * *$ & $* * *$ & $* * *$ & $* * *$ & $* * *$ \\
\hline \multicolumn{2}{|c|}{ Protease } & * & 0.08 & NS & NS & * & NS & NS & NS & NS & NS & NS & NS & NS & NS \\
\hline \multicolumn{2}{|c|}{ RFFS $\times$ protease } & * & NS & NS & NS & * & NS & NS & NS & NS & NS & NS & NS & NS & NS \\
\hline
\end{tabular}

a,b,c Means bearing uncommon superscripts within a column are significantly different at NS = non-significant; ${ }^{*} P<0.05 ;{ }^{* *} P<0.01 ;{ }^{* * *} P<0.00$; ${ }^{1} \mathrm{RFFS}=$ raw, full-fat soybean (SBM was replaced by RFFS at zero, 15 and $25 \%$, equivalent to zero, 45 and $75 \mathrm{~g} / \mathrm{kg}$ of diet, respectively); SEM = standard error of means. A 15000 $\mathrm{PROT} / \mathrm{kg}=15,000$ units of protease $/ \mathrm{kg}$ of diet, equivalent to $200 \mathrm{mg}$ of protease $/ \mathrm{kg}$ of diet

$(P<0.05)$ values of lysine were significantly increased due to supplementation of diets with that of microbial protease.

\section{Discussion}

\section{Diets, performance parameters and internal organ} development

The variations in nutrient contents between the samples of RFFS used in this and other studies may be due to various reasons, including crop variety, processing, and geographical origin [40, 41]. The lower contents of AA in the RFFS in the current study may be largely due to the high fat (oil) content of the material.

The response of birds in terms of FI, BWG and FCR was affected over the 0 to 35 -day period due to the high concentration of TI in the dietary treatments, with one diet close to $10,200 \mathrm{TIU} / \mathrm{g}$, which is beyond the threshold level for non-ruminant animals [42]. However, significant improvements were observed in BWG and FCR during day 0 to 24 due to microbial protease supplementation. The current results are consistent with those of other researchers $[1,43]$ who reported that protease can break down both the stored proteins and the protein-like anti-nutrients and subsequently improve nutrient digestibility. Although not investigated in the current study, the exogenous protease may have complemented the effects of endogenous enzymes, and altered the digestibility of nutrients and possibly feed passage rate $[44,45]$.

The weight of most of the internal organs of the birds, including the gizzard and proventriculus, pancreas, small intestine (SI), heart and spleen, was increased by increasing inclusion level of RFFS in diets. This finding partially agrees with those of other researchers $[46,47]$ who reported that birds fed diets containing RFFS had heavier pancreas and duodenum. The reasons for the increased weights of these internal organs may be a response in form cellular hypertrophy or hyperplasia. The crude fibre content of RFFS was higher than that of commercial SBM and be intact due to lack of processing. In a previous study, we observed an increased weight of the pancreas in birds fed diets containing RFFS [48]. The small intestine, particularly duodenum is anatomically close to the pancreas and it was also similarly affected because of increasing levels of RFFS in diets. This result is supported by reports of other researchers [49]. The relationship between the body weight and visceral organs, in general needs to be considered as the former was reduced by the effect of RFFS, so that the relative weight of the latter became accentuated. 
Table 9 Effects of protease and RFFS supplementations on the coefficient of standardized ileal digestibility of CP and AA of broilers at day 24

\begin{tabular}{|c|c|c|c|c|c|c|c|c|c|c|c|c|c|c|c|}
\hline \multirow{2}{*}{$\begin{array}{l}\text { RFFS' } \\
(\mathrm{g} / \mathrm{kg})\end{array}$} & \multirow{2}{*}{$\begin{array}{l}\text { Protease } \\
\text { (PROT/kg) }\end{array}$} & \multirow[t]{2}{*}{$\mathrm{CP}$} & \multicolumn{9}{|c|}{ Indispensable amino acids } & \multicolumn{4}{|c|}{ Dispensable amino acids } \\
\hline & & & His & $\operatorname{Arg}$ & Thr & Lys & Met & Val & He & Leu & Phe & Ser & Gly & $\mathrm{Al}$ & Pro \\
\hline \multirow[t]{2}{*}{$\overline{0}$} & 0 & $0.804^{b}$ & 0.873 & 0.932 & 0.851 & 0.887 & 0.966 & 0.847 & 0.853 & 0.864 & 0.867 & 0.860 & 0.828 & 0.870 & 0.853 \\
\hline & 15,000 & $0.840^{\mathrm{a}}$ & 0.894 & 0.921 & 0.858 & 0.896 & 0.968 & 0.860 & 0.861 & 0.871 & 0.872 & 0.859 & 0.811 & 0.872 & 0.848 \\
\hline \multirow[t]{2}{*}{45} & 0 & $0.811^{\mathrm{ab}}$ & 0.868 & 0.916 & 0.837 & 0.875 & 0.963 & 0.821 & 0.824 & 0.840 & 0.848 & 0.827 & 0.780 & 0.837 & 0.826 \\
\hline & 15,000 & $0.799^{b}$ & 0.869 & 0.918 & 0.839 & 0.884 & 0.971 & 0.832 & 0.833 & 0.848 & 0.848 & 0.836 & 0.800 & 0.848 & 0.831 \\
\hline \multirow[t]{2}{*}{75} & 0 & $0.785^{b}$ & 0.841 & 0.897 & 0.810 & 0.850 & 0.961 & 0.789 & 0.780 & 0.819 & 0.815 & 0.806 & 0.761 & 0.826 & 0.815 \\
\hline & 15,000 & $0.803^{b}$ & 0.853 & 0.907 & 0.825 & 0.873 & 0.962 & 0.803 & 0.802 & 0.823 & 0.830 & 0.812 & 0.770 & 0.828 & 0.813 \\
\hline \multicolumn{2}{|l|}{ SEM } & 0.004 & 0.005 & 0.004 & 0.004 & 0.004 & 0.002 & 0.006 & 0.007 & 0.006 & 0.005 & 0.005 & 0.006 & 0.004 & 0.005 \\
\hline \multicolumn{16}{|c|}{ Main effects } \\
\hline \multicolumn{2}{|l|}{0} & 0.822 & $0.884^{a}$ & $0.927^{a}$ & $0.855^{\mathrm{a}}$ & $0.891^{a}$ & 0.967 & $0.853^{a}$ & $0.857^{\mathrm{a}}$ & $0.868^{a}$ & $0.869^{a}$ & $0.859^{a}$ & $0.819^{a}$ & $0.871^{a}$ & $0.851^{a}$ \\
\hline \multicolumn{2}{|l|}{45} & 0.805 & $0.869^{a}$ & $0.917^{b}$ & $0.838^{b}$ & $0.879^{b}$ & 0.967 & $0.827^{b}$ & $0.829^{b}$ & $0.844^{b}$ & $0.848^{b}$ & $0.831^{b}$ & $0.790^{b}$ & $0.843^{b}$ & $0.829^{b}$ \\
\hline \multirow[t]{3}{*}{75} & & 0.794 & $0.847^{b}$ & $0.902^{c}$ & $0.818^{b}$ & $0.861^{c}$ & 0.961 & $0.796^{c}$ & $0.791^{c}$ & $0.821^{b}$ & $0.822^{c}$ & $0.809^{c}$ & $0.765^{c}$ & $0.827^{b}$ & $0.814^{b}$ \\
\hline & 0 & 0.800 & 0.861 & 0.915 & 0.833 & $0.871^{b}$ & 0.963 & 0.819 & 0.819 & 0.841 & 0.843 & 0.831 & 0.789 & 0.844 & 0.831 \\
\hline & 15,000 & 0.814 & 0.872 & 0.915 & 0.841 & $0.884^{a}$ & 0.967 & 0.831 & 0.832 & 0.847 & 0.850 & 0.836 & 0.793 & 0.849 & 0.831 \\
\hline \multicolumn{16}{|c|}{ Sources of variation } \\
\hline \multicolumn{2}{|c|}{ RFFS } & $* *$ & $* * *$ & $* * *$ & $* * *$ & $* *$ & NS & $* * *$ & $* * *$ & $* *$ & $* * *$ & $* * *$ & $* * *$ & $* * *$ & $* * *$ \\
\hline \multicolumn{2}{|c|}{ Protease } & * & NS & NS & NS & * & NS & NS & NS & NS & NS & NS & NS & NS & NS \\
\hline \multicolumn{2}{|c|}{ RFFS $\times$ protease } & * & NS & NS & NS & NS & NS & NS & NS & NS & NS & NS & NS & NS & NS \\
\hline
\end{tabular}

a,b,c Means bearing uncommon superscripts within a column are significantly different at NS = non-significant; ${ }^{*} P<0.05 ;{ }^{* *} P<0.01 ;{ }^{* * *} P<0.001 ;{ }^{1} \mathrm{RFFS}=$ raw full-fat soybean (SBM was replaced by RFFS at zero, 15 and $25 \%$, equivalent to zero, 45 and $75 \mathrm{~g} / \mathrm{kg}$ of diet, respectively); SEM = standard error of means. A 15000 $\mathrm{PROT} / \mathrm{kg}$ of diet $=15,000$ units of protease $/ \mathrm{kg}$ of diet, equivalent to $200 \mathrm{mg}$ of protease $/ \mathrm{kg}$ of diet

Ileal digestibility of amino acids and crude protein

Increasing the level of RFFS in diets significantly increased the loss of basal endogenous loss of ileal CP and AA; consequently, reducing the AID and the corresponding SID. These results are inconsistent with those of Clarke and Wiseman [12] who reported that the AID and SID of AA did not correlate with TI levels. The digesta collected from the ileum may contain both dietary undigested materials and endogenous protein and AA [50]. However, the results agree with that of deCoca-Sinova et al. [51] who reported that the apparent digestibility of $\mathrm{N}$ and AA in broilers varies with SBM samples, with greater values corresponding to lower concentration of TI in diets. Moreover, Barth et al. [52] explained that the ingestion of food containing TI influenced $\mathrm{N}$ balance by increasing the outflow of amino acids from endogenous secretions rather than through the loss of dietary amino acids.

The AID and SID of most dispensable and indispensable amino acids assessed at d 24 were significantly reduced by increasing inclusion level of RFFS. These results are in contrast with those of Frikha et al. [53] who reported that the SID of $\mathrm{CP}$ and lysine in broilers was increased at day 21 due to the inclusion of soybeans with high $\mathrm{KOH}$ and TIA values. The current results are supported by other researchers [54] who reported a reduction on the apparent digestibility of nutrients when raw soybean meal was fed to broiler chicks. Similarly, Gilani et al. [8] indicated that the high concentrations of ANF in diets from grain legumes are responsible for poor digestibility of protein. The reduction in AID and SID of CP and AA in the current study may be linked to the increased loss of basal endogenous ileal CP and AA. However, when the diets were supplemented with microbial protease, the basal endogenous loss of ileal CP was reduced. This led to increase in the AID and SID of $\mathrm{CP}$ although this was not significant. The current finding partially agree with those of previous researchers [55-57] who observed an increase in AID of AA in poultry and piglets and health benefits in response to inclusion of microbial protease in the diets.

Protease supplementation significantly improved the AID and SID of lysine. This partially agrees with the finding of Liu et al. [58] who observed a 9\% improvement in apparent digestibility of AA in broilers fed a corn-sorghum-based diet when supplemented with protease. It is not clear why lysine was the only indispensable AA to significantly respond in the current study but it may be related to its digestibility status in RFFS. No reasons could be proffered for the lack of effect of the test product on the digestibility of methionine, which was not affected. 


\section{Conclusion}

This study showed that some commercial SBM could be replaced $(\leq 25 \%)$ by RFFS in broiler diets if the diets are supplemented with the right protease. Body weight gain seemed to be the most affected by the high levels of TI. It is evident from the present study that the test microbial protease could reduce the adverse impact of dietary ANF, particularly TI, on the body weight gain and feed efficiency during up to the end of the grower phase. One major area of action of the protease appears to be the reduction in the basal endogenous loss of $\mathrm{CP}$ and $\mathrm{AA}$ at the ileum, leading to an increase in the AID and SID of $\mathrm{CP}$ and AA. Further studies may be required to establish the direct impact of the test protease on RFFS protein and the differing responses that were observed for methionine and lysine.

\section{Abbreviations}

AA: Amino acids; AEC: Animal Ethics Committee; AID: Apparent ileal digestibility; ANF: Anti-nutritional factors; BWG: Body weight gain; CP: Crude protein; d: day; ECPF: Endogenous crude protein flow; EIAAF: Endogenous ileal amino acid flow; FCR: Feed conversion ratio; Fl: Feed intake; GLM: General linear model; IAAF: Ileal amino acids outflow; ICPF: Ileal crude protein outflow; ME: Metabolizable energy; MJ: Mega joule; N: Nitrogen; NFD: Nitrogen-free diet; NSI: Nitrogen solubility index; RFFS: Raw full fat soybean; SBM: Soybean meal; SI: Small intestine; SID: Standardized ileal digestibility; Ti: Titanium; TI: Trypsin inhibitors; TIU: Trypsin inhibitors unit; UA: urease activity

\section{Acknowledgements}

This research was supported by funding from DSM Nutritional Products, Animal Nutrition and Health, Asia-Pacific and the University of New England, Australia.

\section{Ethical approval and consent to participate}

The article does not contain any studies with human subjects performed by the authors. The experiment was approved by the University's Animal Ethics Committee (Authority No: AEC15-044) and conducted the Animal House of the University of New England, Australia.

\section{Availability of data and materials}

The datasets used and/or analysed during this study are available from the corresponding author on request.

\section{Funding}

This study was partially funded by DSM Nutritional Products, Animal Nutrition and Health, Asia-Pacific and the University of New England, Australia.

\section{Authors' contributions}

$\mathrm{ME}$, as the lead author was in charge of all research work, including designing the protocol, carrying out the experiment and writing the manuscript. RM participated in the acquisition of data and analysis of. PI, as a supervisor to the lead author, was involved in design and execution of the study, and approved the final manuscript. All authors read and approved the final manuscript.

\section{Consent for publication}

Not applicable.

\section{Competing interests}

The authors declare that they have no competing interests.

\section{Publisher's Note}

Springer Nature remains neutral with regard to jurisdictional claims in published maps and institutional affiliations.

\section{Author details}

${ }^{1}$ School of Environmental and Rural Sciences, University of New England, Armidale, NSW 2351, Australia. ${ }^{2}$ DSM Nutritional Products, Animal Nutrition and Health, 30 Pasir Panjang Road \#13-31 Mapletree, Business City 117440, Singapore. ${ }^{3}$ Ethiopian Institute of Agricultural Research, Addis Ababa, Ethiopia.

Received: 24 April 2017 Accepted: 27 August 2017

Published online: 16 October 2017

\section{References}

1. Pettersson D, Pontoppidan K. Soybean meal and the potential for upgrading its feeding value by enzyme supplementation. In: El-Shemy A, editor. Soybean - bio-active compounds, pp. Intech, open access Publisher; 2013. p. 288-307.

2. Shi ESR, Lu J, Tong HB, Zou JM, Wang KH. Effects of graded replacement of soybean meal by sunflower seed meal in laying hen diets on hen performance, egg quality, egg fatty acid composition, and cholesterol content. J Appl Poult Res. 2012;21:367-74

3. Popescu A, Criste R. Using full fat soybean in broiler diets and its effect on the production and economic efficiency of fattening. J Cen Eur Agri. 2003;4:167-74.

4. Liu BL, Rafiq A, Tzeng YM, Rob A. The induction and characterization of phytase and beyond. Enzym Microb Technol. 1998;22:415-24.

5. Newkirk, R. 2010. Soybean. Feed industry guide,1st edition Canadian International Grains Institute, pp.48. Avaiable online: http://www.cigi.ca/ feed.htm

6. Erdaw MM, Perez-Maldonado RA, Bhuiyan M, lji PA. Physicochemical properties and enzymatic in vitro nutrient digestibility of full-fat soybeans meal. J Food Agri Environ. 2016a;14(8):5-91.

7. Erdaw MM, Perez-Maldonado AR and lji PA. Physiological and health-related response of broiler chickens fed diets containing raw, full-fat soybean meal supplemented with microbial protease. Anim Physi Anim Nutri. ID: JAPAN-Nov-16-804R4. 2017, accepted.

8. Gilani GS, Xiao CW, Cockell KA. Impact of antinutritional factors in food proteins on the digestibility of protein and the bioavailability of amino acids and on protein quality. Bri J Nutr. 2012;108:S315.

9. Banaszkiewicz T. Nutritional value of soybean meal. In: El-Shemy HA, editor. Soybean and nutrition.. InTech, Rijeka, Croatia; 2011. p. 1-20.

10. Dourado LRB, Pascoal LAF, Sakomura NK, Costa FGP, Biagiot TID. Soybeans (Glycine max) and soybean products in poultry and swine nutrition. In: Dora Krezhova (Ed) recent trends for enhancing the diversity and quality of soybean products. InTech, Rijeka, Croatia; 2011. p. 175-90.

11. Barth CA, Lunding B, Schmitz M, Hagemeister H. Soybean trypsin inhibitor (s) reduce absorption of exogenous and increase loss of endogenous protein in miniature pigs. J Nutr. 1993;123:2195-200.

12. Clarke $E$, Wiseman J. Effects of variability in trypsin inhibitor content of soya bean meals on true and apparent ileal digestibility of amino acids and pancreas size in broiler chicks. Anim Feed Sci Technol. 2005;121:125-38.

13. Clemente A, Jimenez E, Marin-Manzano MC, Rubio LA. Active Bowman-Birk inhibitors survive gastrointestinal digestion at the terminal ileum of pigs fed chickpea-based diets. J Sci food Agri. 2008;88:513-21.

14. Erdaw MM, Bhuiyan M, lji PA. Enhancing the nutritional value of soybeans for poultry through supplementation with new-generation feed enzymes. World Poult Sci J. 2016b;72:307-22.

15. Ao T. Using exogenous enzymes to increase the nutritional value of soybean meal in poultry diet. In: El-Shemy H, editor. Soybean and nutrition. InTech, Rijeka, Croatia; 2011. p. 201-14.

16. Bedford MR, Schulze H. Exogenous enzymes for pigs and poultry. Nutr Res Reviews. 1998;11:91-114.

17. Martinez-Amezcua CM, Parsons C, Baker DH. Effect of microbial phytase and citric acid on phosphorus bioavailability, apparent metabolizable energy, and amino acid digestibility in distillers dried grains with solubles in chicks. Poult Sci. 2006;85:470-5.

18. Adeola O, Cowieson A. Board-invited review: opportunities and challenges in using exogenous enzymes to imprve no-nruminant animal production. J Anim Sci. 2011:89:3189-218.

19. Erdaw MM, Perez-Maldonado AR, Bhuiyan M, lji PA. Effects of diet containing raw full-fat soybean meal and supplemented with high-impact protease on relative weight of pancreas for broilers. In the Proceedings of 
31st Biennial (Australian \& New-Zealand Societies) Conf. Anim. Prod. 2016c; 4-7 July 2016, Glenelg, Adelaide, Australia.

20. Erdaw MM, Perez-Maldonado AR, Perez-Maldonado RA, Bhuiyan M, Iji PA. Partial replacement of commercial soybean with raw full-fat soybeans meal and supplemented with varying levels of protease in diets of broiler chickens. S African J Anim Sci. 2017a;47:61-71. https://doi.org/10.4314/sajas. v47i1.5

21. Erdaw MM, Shubiao W, Perez-Maldonado AR, lji PA. Growth and physiological responses of broiler chickens to diets containing raw full-fat soybean meal and supplemented with a high-impact microbial protease. Asian-Australas J Anim Sci. 2017b; https://doi.org/10.5713/ajas.16.0714.

22. Erdaw MM, Perez-Maldonado RA, Bhuiyan M, lji PA. Physicochemical properties and enzymatic in vitro nutrient digestibility of full-fat soybeans meal. J Food Agri Environ. 2016d;14(8):5-91.

23. Aviagen Ross 308: Broiler nutrition specifications. Available at: http://ap. aviagen.com/assets/Tech_Center/Ross_Broiler/Ross-308-Broiler-NutritionSpecs-2014r17-EN.pdf. 2009.

24. AOAC. Official method 990.03. Protein (crude) in animal feed, combustion method, in official methods of analysis of AOAC international. AOAC international. VA USA: Arlington; 2006a. p. 30-1.

25. EFSA (European Feed Safety Authority). Safety and efficacy of Ronozyme ${ }^{\circledast}$ ProAct (serine protease) for use as feed additive for chickens for fattening. EFSA. 2009;1185:1-15.

26. lji PA, Saki A, Tivey DR. Body and intestinal growth of broiler chicks on a commercial starter diet. 2. Development and characteristics of intestinal enzymes. Bri Poult Sci. 2001;42:514-22.

27. AOAC. Analysis of Amino acid in Animal Feed using Combustion method Official Int'l method 982, vol. 30. USA: E (a). AOAC International, Arlington, VA; $2006 \mathrm{~b}$.

28. AOCS. Urease activity. Official Method Ba 9-58. Official Methods and Recommended Practices of the AOCS. AOCS. 6th ed. USA: Urbana, IL; 2011 a.

29. Index AOCSNS. (NSI). Official method Ba 11-54. Official methods and recommended practices of the AOCS, AOCS. 6th ed. Urbana, IL: Second Printing; $2011 \mathrm{~b}$.

30. AOCS. Trypsin Inhibitor Activity. Official Method Ba 12-75. Official Methods and recommended Practices of the AOCS. AOCS. 6th ed. Urbana, IL: Second Printing; 2011C.

31. Araba M, Dale N. Evaluation of protein solubility as an indicator of overprocessing soybean meal. Poult Sci. 1990;69:76-83.

32. Cohen SA. Amino acid analysis using precolumn derivatization with 6-aminoquinolyl-N-hydroxysuccinimidyl carbamate. Amino Acid Analysis Protocols. 2000:39-47.

33. Munson LS, Walker PH. Invert sugar in sugars and syrups, general methods. Journal of Society of Chemistry Industry. CAS-8013-17-0 1929; 12: 38.

34. AOAC. Analysis of fat (Crude) or ether extract in animal feed. International official method (6th ed) AOCS, Denver, 920 39. 2009.

35. AOAC. Analysis of fibre in animal feed and pet food. International official method 978, vol. 10. USA: AOAC International, Arlington, VA; 1996.

36. Cohen SA, Michaud DP. Synthesis of a fluorescent derivatizing reagent, 6-aminoquinolyl-N-hydroxysuccinimidyl carbamate, and its application for the analysis of hydrolysate amino acids via high-performance liquid chromatography. Analytical. Biochemist. 1993;211:279-87.

37. Short FJ, Gorton P, Wiseman J, Boorman KN. Determination of titanium dioxide added as an inert marker in chicken digestibility studies. Anim Feed Sci Technol. 1996;9:215-21.

38. Minitab- 17 Statistical Software. [computer software]. State college, PA: Minitab, Inc. 2013.

39. Hong KJ, Lee CH, Kim SW. Aspergillus oryzae GB-107 fermentation improves nutritional quality of food soybeans and feed soybean meals. J Medicinal Food. 2004;7:430-5.

40. Swick RA. Selecting soy protein for animal feed. In: 15th Ann ASAIM southeast Asian feed technolo and nutri workshop. Indonesia: Bali. p. 2007.

41. Baker KM, Utterback PL, Parsons CM, Stein HH. Nutritional value of soybean meal produced from conventional, high-protein, or low-oligosaccharide varieties of soybeans and fed to broiler chicks. Poult Sci. 92011:390-5.

42. Barletta A. Introduction: current market and expected developments. In: Bedford MR, PartridgE GG, editors. Enzymes in farm animal nutrition CABI. UK: Wallingford; 2011. p. 1-11.

43. Mayorga ME, Vieira SL, Sorbara JOB. Effects of a mono-component protease in broiler diets with increasing levels of trypsin inhibitors. XXII Latin American Poult Congr, in Buenos Aires, in September. 2011; 6-9, Argentina. https://en.engormix.com/poultryindustry/articles/effects-mono-componentprotease-t35031.htm.

44. Onifade AA, Al-Sane NA, Al-Musallam AA, Al-Zarban S. A review: potentials for biotechnological applications of keratin-degrading microorganisms and their enzymes for nutritional improvement of feathers and other keratins as livestock feed resources. Bioresour Technol. 1998;66:1-11.

45. Murugesan GR, Romero LF, Persia ME. Effects of protease, phytase and a bacillus sp. direct-fed microbial on nutrient and energy digestibility, ileal brush border digestive enzyme activity and cecal short-chain fatty acid concentration in broiler chickens. PLoS One. 2014;9:e101888.

46. Mogridge J, Smith T, Sousadias M. Effect of feeding raw soybeans on polyamine metabolism in chicks and the therapeutic effect of exogenous putrescine. J Anim Sci. 1996;74:1897-904.

47. Erdaw MM, Perez-Maldonado AR, Bhuiyan M, lji PA. Response of broiler chicks to cold- or steam-pelleted diets containing raw full-fat soybeans meal. J Appl Poult Rese. 2017c;26:1-13. https://doi.org/10.3382/japr/pfw070.

48. d-Coca-Sinova A, Valencia DG, Jiménez-Moreno E, Lázaro R, Mateos GG. Apparent ileal digestibility of energy, nitrogen, and amino acids of soybean meals of different origin in broilers. Poult Sci. 2008;87:2613-23.

49. Erdaw MM, Perez-Maldonado AR, Bhuiyan M, lji PA. Super-dose levels of protease and phytase enable utilization of raw soybean meals in broiler diets. Proce 27th Australian Poult Sci Symp Febr. 2016:14-7.

50. Laplace JP, Darcy-Vrillon B, Duval-Iflah Y, Raibaud P, Bernard F, Calmes R, Guillaume P. Proteins in the digesta of the pig: amino acid composition of endogenous, bacterial and fecal fractions. Reprod Nutri Dével. 1985;25: 1083-99.

51. Barth CA, Lunding B, Schmitz M, Hagemeister H. Soybean trypsin inhibitor (s) reduce absorption of exogenous and increase loss of endogenous protein in miniature pigs. J Nutr. 1993;23:2195-200.

52. Frikha M, Serrano MP, Valencia DG, Rebollar PG, Fickler J, Mateos GG. Correlation between ileal digestibility of amino acids and chemical composition of soybean meals in broilers at 21 days of age. Anim Feed Sci Technol. 2012;178:103-14.

53. Rocha C, Durau JF, Barrilli LNE, Dahlke F, Maiorka P, Maiorka A. The effect of raw and roasted soybeans on intestinal health, diet digestibility, and pancreas weight of broilers. J Appl Poult Rese. 2014;23:71-9.

54. Guggenbuhl P, Waché $Y$, Wilson JW. Effects of dietary supplementation with a protease on the apparent ileal digestibility of the weaned piglet. J Anim Sci. 2012;90:152-4.

55. Romero L, Plumstead P. Bio-efficacy of feed proteases in poultry and their interaction with other feed enzymes. In the proceedings of 24th Ann Australian Poult Sci Symp Sydney, New South Wales. 2013; Feb 17th -20th.

56. Cowieson AJ, Aureli R, Guggenbuhl P, Fru-Nji F. Possible involvement of myo-inositol in the physiological response of broilers to high doses of microbial phytase. Anim Prod Sci. 2015;55:710-9.

57. Liu S, Selle P, Court S, Cowieson A. Protease supplementation of sorghumbased broiler diets enhances amino acid digestibility coefficients in four small intestinal sites and accelerates their rates of digestion. Anim Feed Sci Technol 2003; 183: 175-183.

58. McCleary BV, Solah V, Gibson TS. Quantitative measurement of total starch in cereal flours and products. J Cereal Sci. 1994:51-8. 